\title{
IN VITRO SYNTHESIS AND TRANSPORT OF BARLEY ENDOSPERM PROTEINS: RECONSTITUTION OF FUNCTIONAL ROUGH MICROSOMES FROM POLYRIBOSOMES AND STRIPPED MICROSOMES
}

\author{
by \\ VERENA CAMERON-MILLS and JOHN INGVERSEN \\ Department of Physiology, Carlsberg Laboratory, \\ Gamle Carlsberg Vej 10, DK-2500 Copenhagen Valby
}

Keywords: Endoplasmic reticulum, membrane transport, hordein, high lysine mutants

\begin{abstract}
Synthesis of hordein, a hydrophobic storage protein of developing barley endosperms, and its transport into the lumen of the endoplasmic reticulum has been studied in vitro. Microsomes of the rough endoplasmic reticulum have been prepared from 20 day old Bomi barley endosperms and their ability to synthesize all the major hordein polypeptides during in vitro cell-free protein synthesis demonstrated. Some $50 \%$ of these hordein polypeptides are discharged into the lumen of the microsome and are consequently inaccessible to chymotrypsin digestion.

Stripped microsomes, derived from rough microsomes by EDTA-treatment, have been combined with detached polysomes from Bomi endosperm during cell-free protein synthesis. An in vitro reconstitution of rough microsomes ensued, with a proportion of all the synthesized hordein polypeptides being discharged vectorially into the microsomal lumen. Both co- and post-translational transport of processed hordein polypeptides has been demonstrated with reconstituted Bomi rough microsomes.

For mutant no. 1508, which is deficient in hordein synthesis, in vitro synthesis of certain hordein polypeptides has only been demonstrated on detached polysomes isolated from mutant endosperms. Not only are mutant rough microsomes unable to synthesize and transport hordein polypeptides, but attempts to reconstitute active hybrid rough microsomes from Bomi polysomes and mutant stripped microsomes or vice versa were unsuccessful.
\end{abstract}

\section{INTRODUCTION}

Major features of the intracellular protein transport in animal cells have been elucidated in recent years (14). In 1975, B LOBEL and DOBBERSTEIN (1) advanced a detailed version

of their "signal hypothesis", which encompasses both the synthesis and membrane transport of secretory proteins. It has been shown that messenger RNA's, coding for a wide range of 
secreted proteins during in vitro cell-free translation yield polypeptides which contain an $\mathrm{NH}_{2}$-terminal extension of 15 to 30 amino acids, when compared with the native product $(7,10$, $11,20)$. The $\mathrm{NH}_{2}$-terminal extension is thought

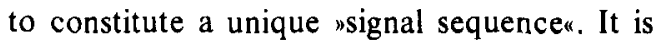
proposed that the signal, on emergence from the ribosome during protein synthesis, interacts with and penetrates some specific area of the endoplasmic reticulum and thereby triggers ribosome-membrane binding. Ionic bonding of the large ribosomal subunit to the membrane $(12,17)$ may stabilize the initial membraneattachment of the signal and also provide the topological conditions for the subsequent transfer of the growing polypeptide across the membrane. Prior to completion of polypeptide synthesis, a peptidase located on the luminal surface of the endoplasmic reticulum, endoproteolytically cleaves off the signal peptide (21). The nascent polypeptides are subsequently released into the lumen, where further modification may precede their further transport and ultimate excretion from the cell. When mRNA translation ceases and all the nascent polypeptides have been released, the bound polysomes may disassemble and detach from the membrane.

While an increasing amount of data regarding the in vitro synthesis of membrane, storage and secreted proteins from animal $(1,2,18,19$, $20,21)$ and bacterial cells $(15,16)$ supports the signal hypothesis, our understanding of plant systems is limited. During endosperm development in barley grains, some 20 days after anthesis, a large part of the protein-synthesizing machinery is directed towards the synthesis of storage proteins (4). Among the major storage proteins, the hordeins are synthesized in vitro on membrane-bound polysomes (5) and are discharged vectorially into the lumen of the endoplasmic reticulum (8). The primary translation products of purified hordein mRNA's are 2 kilodaltons larger than the native hordein polypeptides (6), while the hordein polypep- tides synthesized by rough microsomes are close in size to the native hordein polypeptides (8). Thus, there is strong evidence that the synthesis and deposition of barley endosperm storage proteins follows the scheme outlined for animal secretory proteins in the "signal hypothesis" $(1,2)$.

This paper reports that polysomes detached from Bomi endosperm membranes will bind in vitro to stripped microsomes derived from Bomi rough microsomes, and will synthesize and discharge processed hordein polypeptides into the lumen of the microsomes. Reconstitution of hybrid microsomes from initially membrane-bound polysomes of Bomi wild type endosperm with stripped microsomes from endosperm of the high lysine mutant Ris $\varnothing$ no. 1508 or vice versa, was also attempted in order to investigate the causes of the depression of hordein synthesis in this mutant.

\section{MATERIALS AND METHODS}

\subsection{Chemicals}

HEPES, ATP (disodium salt), GTP (sodium salt), creatine phosphate (disodium salt), creatine kinase (E.C.No.2.7.3.2), DTT, spermidine phosphate, $\alpha$ chymotrypsin and L-amino acids were purchased from Sigma Chemicals. ${ }^{35} \mathrm{~S}$ methionine (specific activity approx. 900 Ci.mmole ${ }^{-1}$ ) was obtained from Radiochemical Center, Amersham, U. K.

HKM buffer A: 20mM-HEPES, pH 7.6, $100 \mathrm{mM}-\mathrm{K}$ acetate, $50 \mathrm{~mm}-\mathrm{Mg}$ acetate, $0.2 \mathrm{M}-$ sucrose and $2 \mathrm{mM}$-DTT.

HKM buffer B: 20mM-HEPES, pH 7.6, $100 \mathrm{~mm}-\mathrm{K}$ acetate, $5 \mathrm{mM}-\mathrm{Mg}$ acetate and 2mM-DTT.

HK buffer C: 20m M-HEPES, pH 7.6, 100mM-K acetate and $2 \mathrm{mM}$-DTT.

\subsection{Plant material}

Barley plants (Hordeum vulgare L.) cv. Bomi and its mutant Risø no. 1508 were grown

Abbreviations: DTT = dithiothreitol; HEPES = N-2-hydroxyethylpiperazine-N'-2-ethane sulfonic acid; HKM = HEPES-K-Mg acetate buffer (see 2.1.); HK = HEPES-K acetate buffer (see 2.1.); Met = methionine; SDS-PAGE $=$ Sodium dodecylsulfate polyacrylamide gel electrophoresis; $\mathrm{TCA}=$ trichloracetic acid. 
in the field. Spikes, harvested 20 days after anthesis, were frozen in liquid nitrogen and stored in polyethylene bags at $-70^{\circ} \mathrm{C}$ for up to 3 months.

\subsection{Polysome isolation}

Polysomes were detached from endosperm membrane fractions with $1 \%$ Triton X-100 and isolated as described previously (5).

\subsection{Rough microsome preparation}

Rough microsomes were prepared from 20 day old Bomi and mutant endosperm as described previously (8).

\subsection{Stripped microsome preparation}

Stripped microsomes were prepared from rough microsomes, originally isolated from Bomi and mutant endosperm. The stripping procedure was one adapted from that of B LOBEL and DOBBERSTEIN (2). Rough microsomes, suspended in HK buffer $\mathrm{C}$ at a concentration of approx. $30 \mathrm{~A}_{260}$ units.ml-1 (cf. 5), were incubated with $30 \mathrm{~mm}$-EDTA for $30 \mathrm{~min}$. This, and all subsequent steps, were performed at $0^{\circ} \mathrm{C}$. Samples of $0.5 \mathrm{ml}$ were then layered on top of $13 \mathrm{ml} 10-55 \%$ continuous sucrose gradients prepared in HK buffer $\mathrm{C}$. After $2 \mathrm{~h}$ centrifugation at $190,000 \times \mathrm{gav}_{\mathrm{av}}$ on a Beckman SW40 rotor, the gradients were tapped from the top with an Auto Densi Flow RIIc (Searle) and continuously monitored for absorbance at 254 and $275 \mathrm{~nm}$. The gradients were collected in $0.5 \mathrm{ml}$ fractions and their sucrose density determined by refractometry. Fractions containing stripped microsomes were pooled, diluted with an equal volume of $\mathrm{HK}$ buffer $\mathrm{C}$ and the material pelleted by centrifuging at $165,000 \mathrm{xg}_{\mathrm{av}}$ for th on a Beckman 50Ti rotor.

Stripped microsomes were also isolated from discontinuous sucrose gradients. $0.5 \mathrm{ml}$ volumes of EDTA-treated microsomes, corresponding to $15 \mathrm{~A}_{260}$ units, were layered on two-step gradients comprising $1.5 \mathrm{ml}$ of $0.30 \mathrm{M}$-sucrose on $6 \mathrm{ml}$ of $0.73 \mathrm{M}$-sucrose. After centrifugation on a Beckman 50Ti rotor at $100,000 \mathrm{xg}_{\mathrm{av}}$ for $\mathrm{lh}$, the pelleted, stripped microsomes were resuspended in HKM buffer B at $100 \mathrm{~A}_{260}$ units.m- $\mathrm{H}^{-1}$ and stored in liquid nitrogen. Ribosomal subunits were obtained from the top $2.5 \mathrm{ml}$ of the discontinuous sucrose gradients.

\subsection{Electron microscopy of rough and stripped microsome preparations}

Rough microsome fractions, removed from discontinuous sucrose gradients (8), were diluted with an equal volume of HKM buffer $B$, and fixed with $2 \%$ glutaraldehyde for $1 \mathrm{~h}$ at $0^{\circ} \mathrm{C}$. The fixed material was pelieted in conical tubes with a bench centrifuge, and then resuspended in $60 \mathrm{~mm}$-phosphate buffer $\mathrm{pH} 7.3$, containing $2 \%$ glutaraldehyde. After further centrifugation, the pellets were given three $10 \mathrm{~min}$ washes in

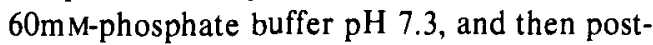
fixed with $1 \%$ osmium tetroxide in the same buffer. The fixed pellets were divided into $1.5 \mathrm{~mm}$ cubes, dehydrated through an alcohol series and embedded in Spurr's low-viscosity epoxy resin. Dehydration and embedding were performed at room temperature. Sections were cut in a Reichert UM-2 microtome, contrasted with uranyl acetate and lead citrate and examined in a Siemens Elmiskop 102.

Stripped microsome fractions, pooled from continuous sucrose gradients, were fixed and prepared for electron microscopy in a similar manner.

\subsection{SDS-PAGE of microsomal and ribosomal proteins}

Samples containing $1.6 \mathrm{~A}_{260}$ units of either detached polysomes, rough microsomes, stripped microsomes or ribosomal subunits were dried down in an air stream and suspended in $20 \mu \mathrm{l}$ $0.1 \mathrm{M}$-Tris base, $1 \mu \mathrm{l} 1 \%$ bromophenol blue, $20 \mu \mathrm{l}$ $30 \%$ sucrose: $5 \%$ SDS and $5 \mu 10.1 \mathrm{M}$-DTT. The samples were dissolved by boiling for $1 \mathrm{~min}$ and $10 \mu 10.2 \mathrm{M}$-iodoacetamide were added $2 \mathrm{~h}$ prior to electrophoresis. Electrophoresis was performed on $15 \%$ polyacrylamide gels, using the buffer system of CHUA and BENNOUN (9), and the proteins were visualized with Coomassie Brilliant Blue R250.

\subsection{Cell-free protein synthesizing system}

Cell-free protein synthesis was performed as previously described (8), except that the incubation was for $30 \mathrm{~min}$. 


\subsection{SDS-PAGE and fluorography of polypep- tides synthesized in the cell-free system}

Cell-free protein synthesis was terminated by the addition of $\mathrm{I} \mathrm{ml} \mathrm{of} 10 \%$ TCA, $10 \mathrm{~mm}-\mathrm{Met}$ and the hordein translation products were extracted into $55 \%$ isopropanol containing $2 \%$ mercaptoethanol, $10 \mathrm{~mm}$-Met and 10mM-EDTA. After removal of insoluble proteins by centrifugation, the isopropanol extracts were dried down and prepared for electrophoresis as described in section 2.7. Electrophoresis was performed on $12.5 \%$ polyacrylamide gels employing the buffer system of CHUA and BENNOUN (9), with native ${ }^{14} \mathrm{C}$-labelled hordeins as markers.

The gels were prepared for fluorography as described by BONNER and LASKEY (3) and exposed to RP Royal X-omat film (Kodak) at $-70^{\circ} \mathrm{C}$ for 4-6 days, and then developed.

\subsection{Preparation of native ${ }^{14} \mathrm{C}$-labelled hordeins}

In vivo ${ }^{14} \mathrm{C}$-labelled hordeins were prepared as described previously (8).

\section{RESULTS}

\subsection{Isolation of rough and stripped microsomes}

Rough microsomes, prepared from homogenates of Bomi and mutant endosperm, were isolated from discontinuous sucrose gradients in which they banded at the interfaces of 1.5-1.7M (band II) and 1.7-2.26M (band I), (8). Polysomes from Bomi and mutant endosperms were obtained by Triton-extraction of the membrane pellet (5). The yield of rough microsomes (bands I and II) and polysomes from Bomi endosperm was more than two-fold greater than the yield of the corresponding fractions from the mutant endosperm (Table I).

Stripped microsomes were derived from rough microsomes by EDTA-mediated ribosome detachment and subsequent isolation of the smooth vesicles. While both rough microsome fractions were suitable source material in the mutant, the presence of protein bodies among the Bomi band I microsomes restricted the preparation of stripped microsomes to band II.

Stripped microsomes were initially isolated

\section{Table I}

Yield of rough microsomes and polysomes from Bomi and mutant no. 1508. Rough microsomes and polysomes were prepared from $\mathbf{2 0}$ day old Bomi and mutant endosperms as described under Materials and Methods (2.3. and 2.4.).

\begin{tabular}{lll}
\hline $\begin{array}{l}\text { Origin of } \\
\text { sub-cellular fraction }\end{array}$ & \multicolumn{2}{c}{$\begin{array}{c}\text { Yield } \\
\mathrm{A}_{260}\end{array}$} \\
\hline Bomits-spike-1 \\
\cline { 2 - 3 } Bomi rough microsomes: & band I & 2.49 \\
band II & 2.69 \\
Mutant rough microsomes: & & 2.70 \\
& band I & 1.10 \\
butand II & 1.12 \\
\hline
\end{tabular}

from EDTA-treated rough microsomes by isopycnic sucrose density centrifugation. Figure $1 B$ shows the $A_{254}$ and $A_{275}$ profiles of a sucrose gradient containing dissociated rough microsomes from mutant endosperm. The small and large ribosomal subunits were found at the top of the gradient at densities of 1.06 and $1.08 \mathrm{~g} \cdot \mathrm{ml}^{-1}$ respectively, while the stripped microsome fraction formed two overlapping peaks in the lower half of the gradient at densities of 1.17 and $1.18 \mathrm{~g} \cdot \mathrm{ml}^{-1}$. A sample of untreated rough microsomes, fractionated on a parallel sucrose gradient, banded at a density of $1.20 \mathrm{~g} \cdot \mathrm{ml}^{-1}$, with a shoulder at $1.18 \mathrm{~g} \cdot \mathrm{ml}^{-1}$ (Figure 1A). The small peak at the top of this gradient (Figure 1A) probably corresponds to the ribosomal subunit peaks in Figure 1B, and thus reflects the physical detachment of a small proportion of the membrane-bound polysomes during ultracentrifugation.

When the two peaks of stripped microsomes were individually pooled and analysed by electron microscopy, the difference in isopycnic density was found to reflect differences in vesicle size. Since vesicle size was not considered to be a critical factor in the reconstitution of rough microsomes, in all subsequent experiments all fractions containing stripped microsomes were pooled, thereby maximising the yield of vesicles. A discontinuous sucrose gra- 


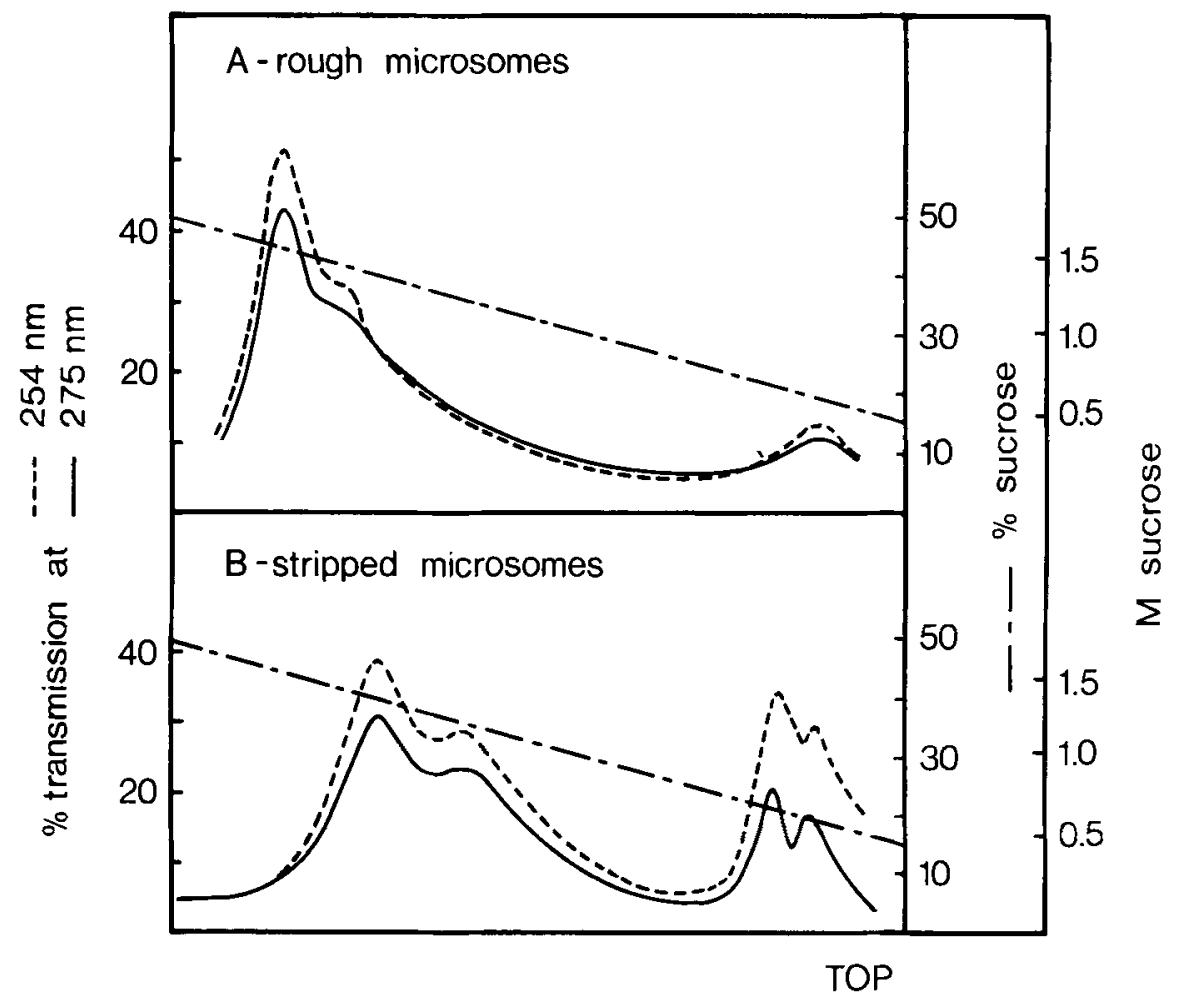

Figure 1. Sucrose density profile of rough and stripped microsomes. Rough microsomes from mutant no. 1508 endosperm, suspended in HK buffer $\mathrm{C}\left(34 \mathrm{~A}_{260}\right.$ units.m/ $\left.\mathrm{ml}^{-1}\right)$, were incubated in $30 \mathrm{mM}$-EDTA for $30 \mathrm{~min}$ at $0^{\circ} \mathrm{C}$ and $0.5 \mathrm{ml}$ samples layered on a $10-55 \%$ continuous sucrose gradient prepared in HK buffer C. After 2 hours centrifugation at 190,000 $\times \mathrm{g}_{\mathrm{av}}$ in a Beckman SW40 rotor, the absorbance of the tapped gradient was monitored at 254 and $275 \mathrm{~nm}(B)$. A sample of untreated rough microsomes was analysed in a parallel gradient prepared in HKM buffer $B,(A)$.

dient was then devised (see Materials and Methods, 2.5.) to permit a one-step purification of stripped microsomes, whereby the stripped microsomes are pelleted and the ribosomal subunits are retained at the $0.30-0.73 \mathrm{M}$-sucrose interface.

The minimum concentration of EDTA sufficient to bring about ribosomal disaggregation was determined, since excessive amounts of EDTA in stripped microsome preparation may impair their potential for reconstitution (2). Stripped microsomes were prepared from Bomi rough microsomes by treatments with from 20 to 50mM-EDTA. The presence of ribosomal proteins in association with the stripped microsomes was then determined by SDS-PAGE (Figure 2). The Coomassie blue stained proteins from the stripped microsomes (tracks 2, 3, 4 and 5) are characteristic of high molecular weight membrane proteins and have a low mobility in $15 \%$ polyacrylamide gels. The smaller ribosomal proteins, derived from purified Bomi detached-polysomes (see Materials and Methods 2.5.), have a high mobility in these gels (track 1) and are clearly distinguishable from the membrane proteins.

The absence of ribosomal proteins from each of the stripped microsomal preparations indicated that $20 \mathrm{~mm}$-EDTA would ensure complete ribosome detachment. Where the concentration of microsomes exceeded $30 \mathrm{~A}_{260}$ units $\mathrm{ml}^{-1}$, a $30 \mathrm{~mm}-E D T A$ treatment was routinely used. Between 60 and $70 \%$ of both Bomi and mutant rough microsomes was recovered as stripped 


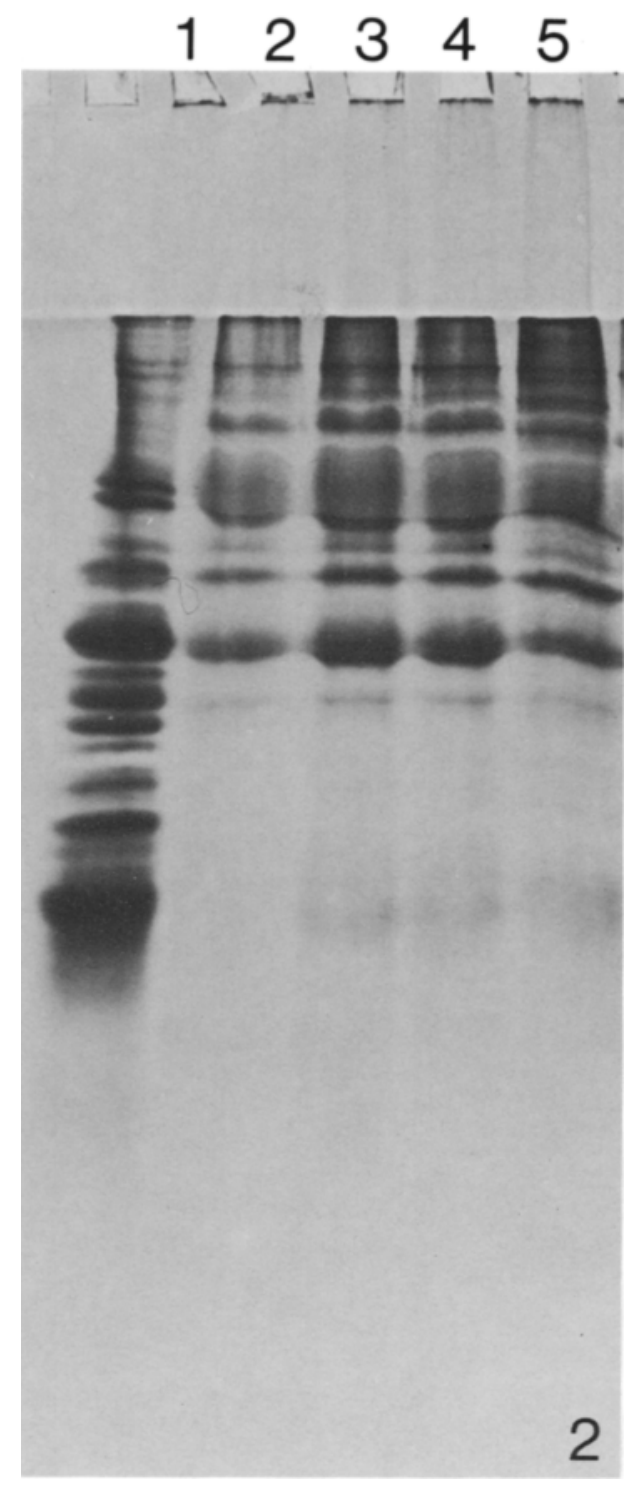

Figure 2. SDS-PAGE of proteins from stripped microsomes prepared at various EDTA concentrations. Rough microsomes from Bomi endosperm, suspended in $\mathrm{HK}$ buffer $\mathrm{C}\left(30 \mathrm{~A}_{260}\right.$ units $\left.\cdot \mathrm{ml}^{-1}\right)$, were incubated in $20-50 \mathrm{~mm}$-EDTA for $30 \mathrm{~min}$ at $0^{\circ} \mathrm{C}$ and then $0.5 \mathrm{ml}$ samples layered on discontinuous sucrose gradients comprising $1.5 \mathrm{ml}$ of $0.30 \mathrm{M}$-sucrose on top of $6 \mathrm{ml}$ of $0.73 \mathrm{M}$-sucrose prepared in HK buffer $\mathrm{C}$. After 2 hours centrifugation at $165,000 \times \mathrm{g}_{\mathrm{av}}$ in a Beckman 50Ti rotor, the microsomal pellets were prepared for SDS-PAGE. The $15 \%$ polyacrylamide gels were loaded with $1.6 \mathrm{~A}_{260}$ units of material per track and subsequently stained in Coomassie Brilliant Blue. The gels show proteins from Bomi detached polysomes, track 1; and proteins from microsomes after treatment with $20,30,40$ and $50 \mathrm{~mm}$-EDTA, tracks $2,3,4$ and 5 . microsomes, in terms of $A_{260}$ units. The detachment of ribosomes leads to a decrease in $\mathrm{A}_{260} / \mathrm{A}_{280}$ ratio from 1.8 to 1.3 .

\subsection{Characterization of rough and stripped microsomes}

A number of techniques were pursued to verify the purity of the stripped microsome preparations. Figure 3 shows an electrophorogram of the proteins present in stripped microsomes (track 3) and ribosomal subunits (track 4) derived from EDTA-treated rough microsomes (track 2) of Bomi (A) and mutant (B) endosperm. The samples were co-electrophoresed with marker proteins from detached polysomes (Track 1). In the stripped microsome preparations from both Bomi and mutant, it is clearly seen that EDTA treatment has led to a removal of ribosomal proteins from the membrane fractions. While some remnants of ribosomal protein are apparent in the stripped microsome fractions, it should be appreciated that the use of $1.6 \mathrm{~A}_{260}$ units per track leads to a greater loading of stripped than rough microsomes.

Figure 3 also reveals that the membrane proteins in stripped microsomes (tracks $3 \mathrm{~A}$ and $3 \mathrm{~B}$ ) and those high molecular weight membrane proteins detached by EDTA-treatment (tracks 4A and 4B) show different band patterns, when the preparations from Bomi and mutant endosperm are compared.

The purity of the stripped microsomal fractions was then investigated by electron microscopy. In Figure 4, a comparison of the rough microsomes (band II) (a) and the derived stripped microsomes (b) from Bomi endosperm can be made. A marked contrast between the ribosome-studded rough microsomes and the stripped vesicles is apparent. The electron-dense particles adhering to the stripped microsome surface may be large ribosomal subunits left after the preferential release of the small subunit at low EDTA concentrations (17).

The removal of membrane-bound polysomes from mutant rough microsomes is also evident from a comparison of mutant rough (Figure 5a) and stripped microsomes (Figure $5 b$ ). In this instance, $30 \mathrm{~mm}$-EDTA was sufficient to detach both small and large ribosomal subunits. Since 


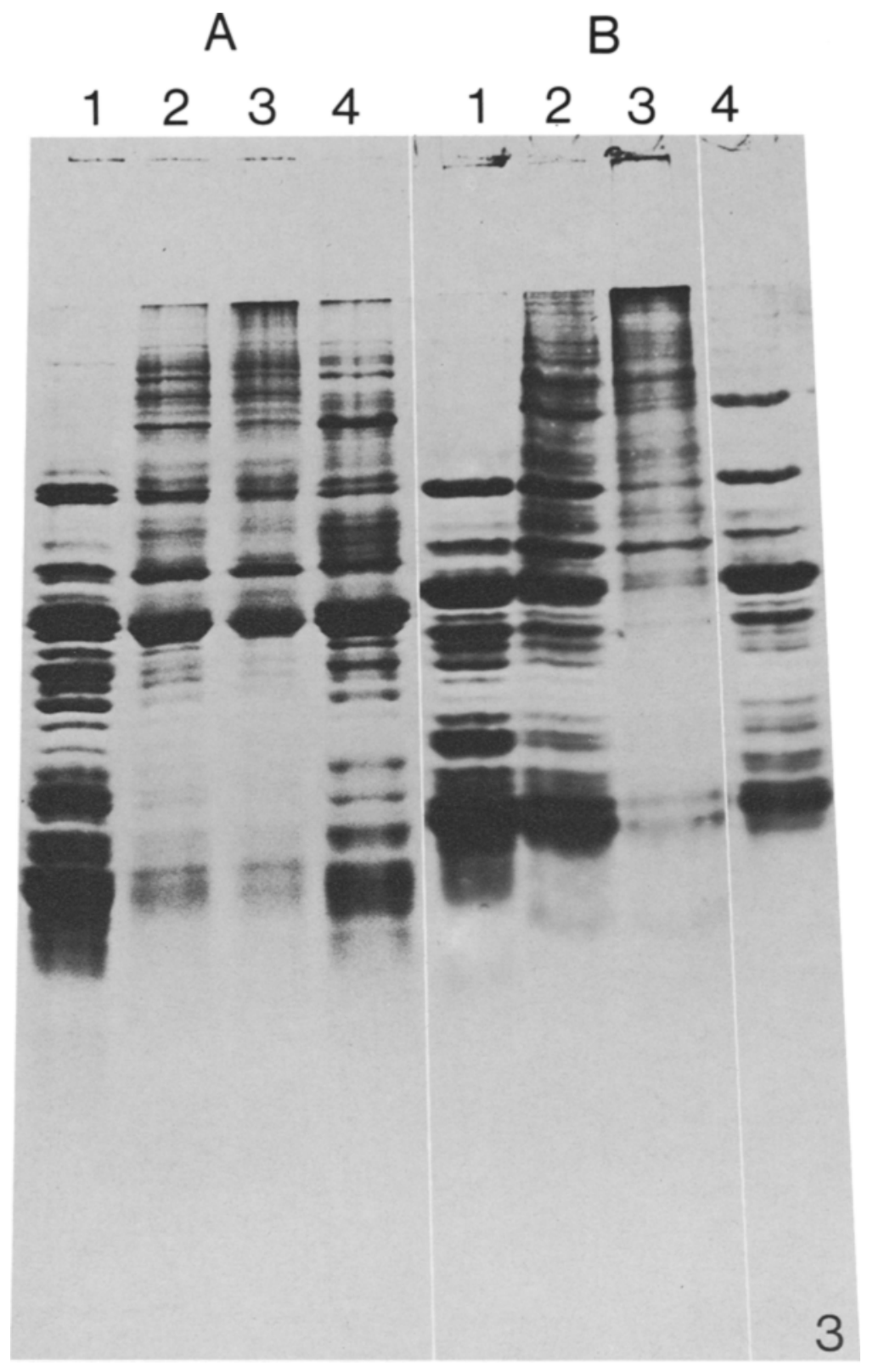

Figure 3. SDS-PAGE of proteins from rough and stripped microsomes and from ribosomal subunits. Stripped microsomes and detached ribosomal subunits from Bomi and mutant no. 1508 endosperms were isolated as described under Figure 2 and then prepared for SDS-PAGE. Samples were co-electrophoresed with untreated rough microsomes and purified detached polysomes. Each track in the $15 \%$ polyacrylamide gels was loaded with $1.6 \mathrm{~A}_{260}$ units. The Coomassie Brilliant Blue stained gel shows proteins from detached polysomes in track 1; rough microsomes in track 2; stripped microsomes in track 3; and ribosomal subunits in track 4 from Bomi (A) and mutant endosperm (B). 

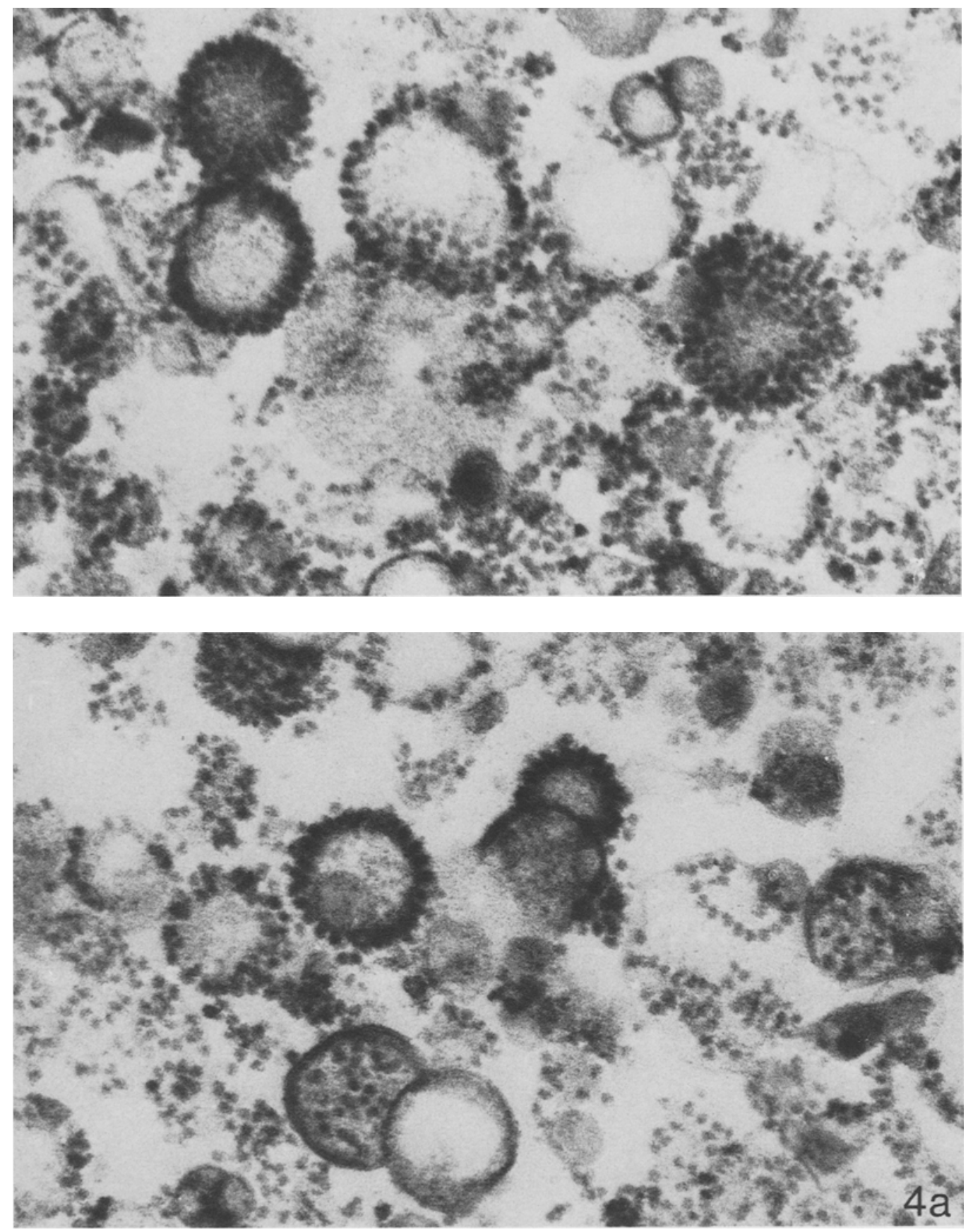

Figure 4. Rough and stripped microsomes from Bomi endosperm. Rough microsomes were prepared from 20 day old Bomi endosperms by discontinuous sucrose gradient centrifugation of the membrane fraction derived from the homogenized tissue. Stripped microsomes were obtained from the rough microsomes by a 30 min treatment with $30 \mathrm{~mm}$-EDTA followed by centrifugation at $190,000 \times \mathrm{gav}$ through a $10-55 \%$ continuous sucrose gradient for 2 

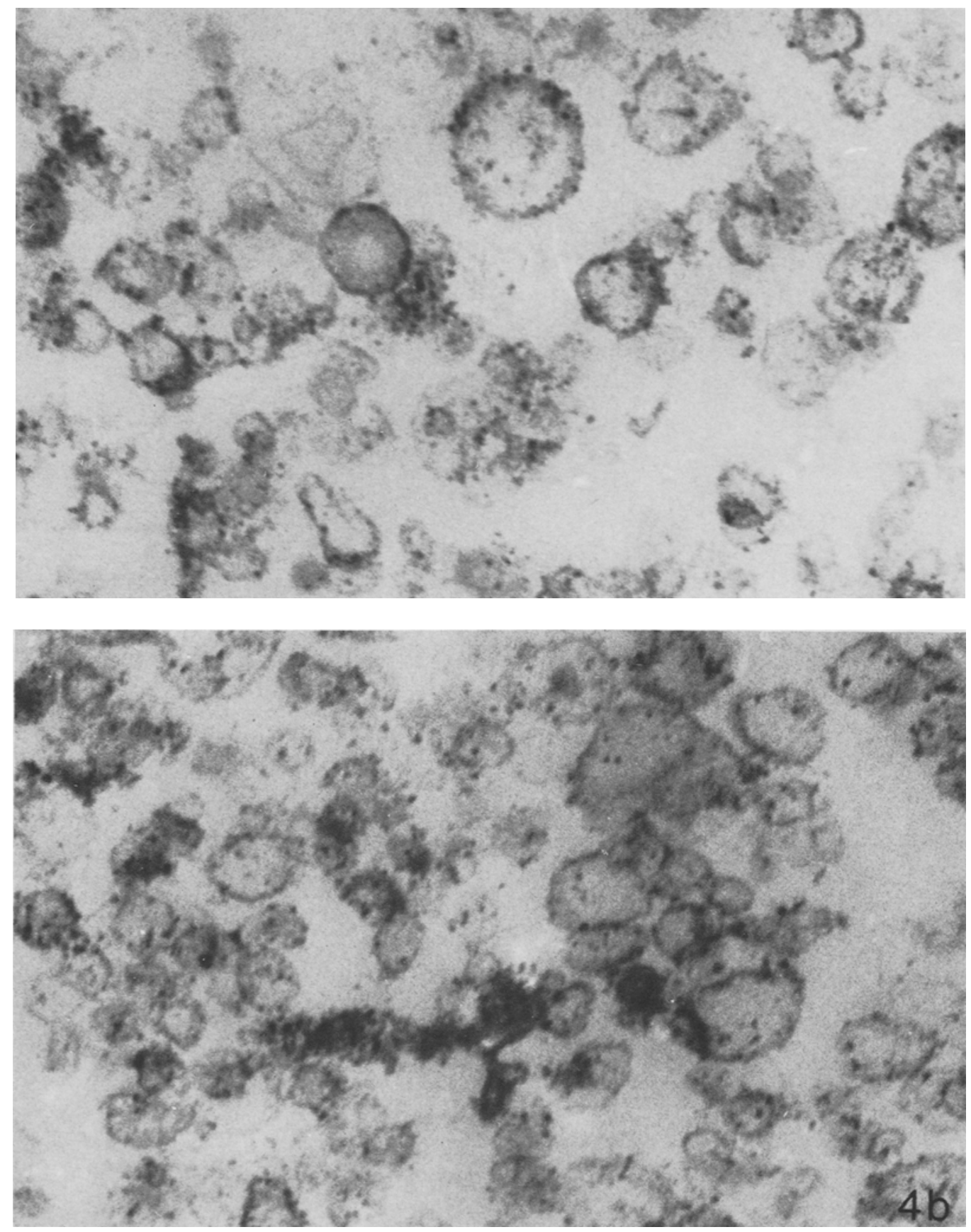

hours on a Beckman SW40 rotor. The material banding at densities of $1.17-1.18 \mathrm{~g} \cdot \mathrm{m}^{-1}$ was isolated, fixed, stained, embedded and sectioned for electron microscopy. (a) shows rough microsomes and (b) stripped microsomes. Magnification: $a$ and $b, \times 104,000$. 

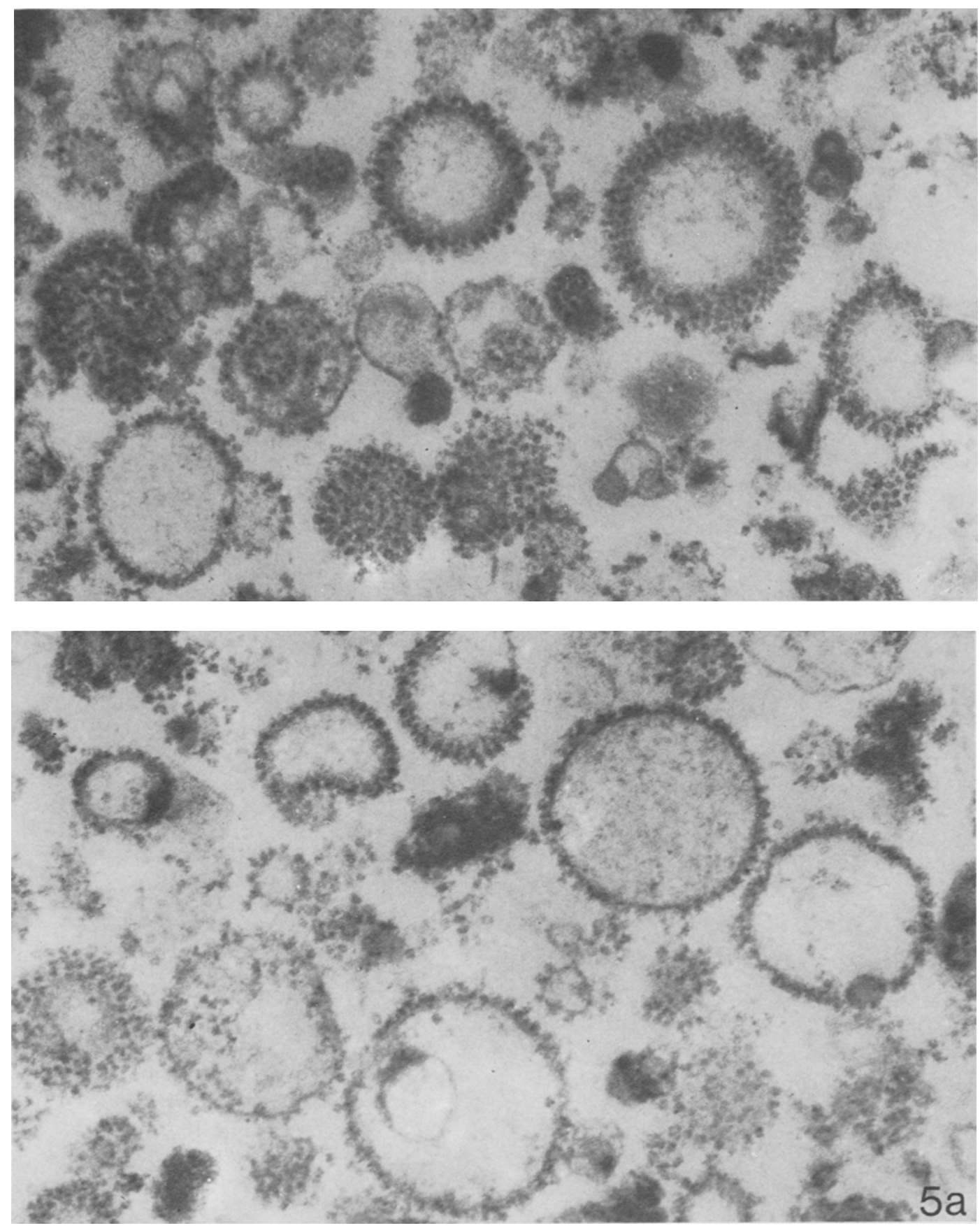

Figure 5. Rough and stripped microsomes from mutant no. 1508 endosperm. Rough and stripped microsomes were derived from 20 day old mutant endosperms and prepared for electron microscopy as described in Figure 4. (a) shows rough microsomes and (b) stripped microsomes. Magnification: a, × 74,000; b, ×60,000. 


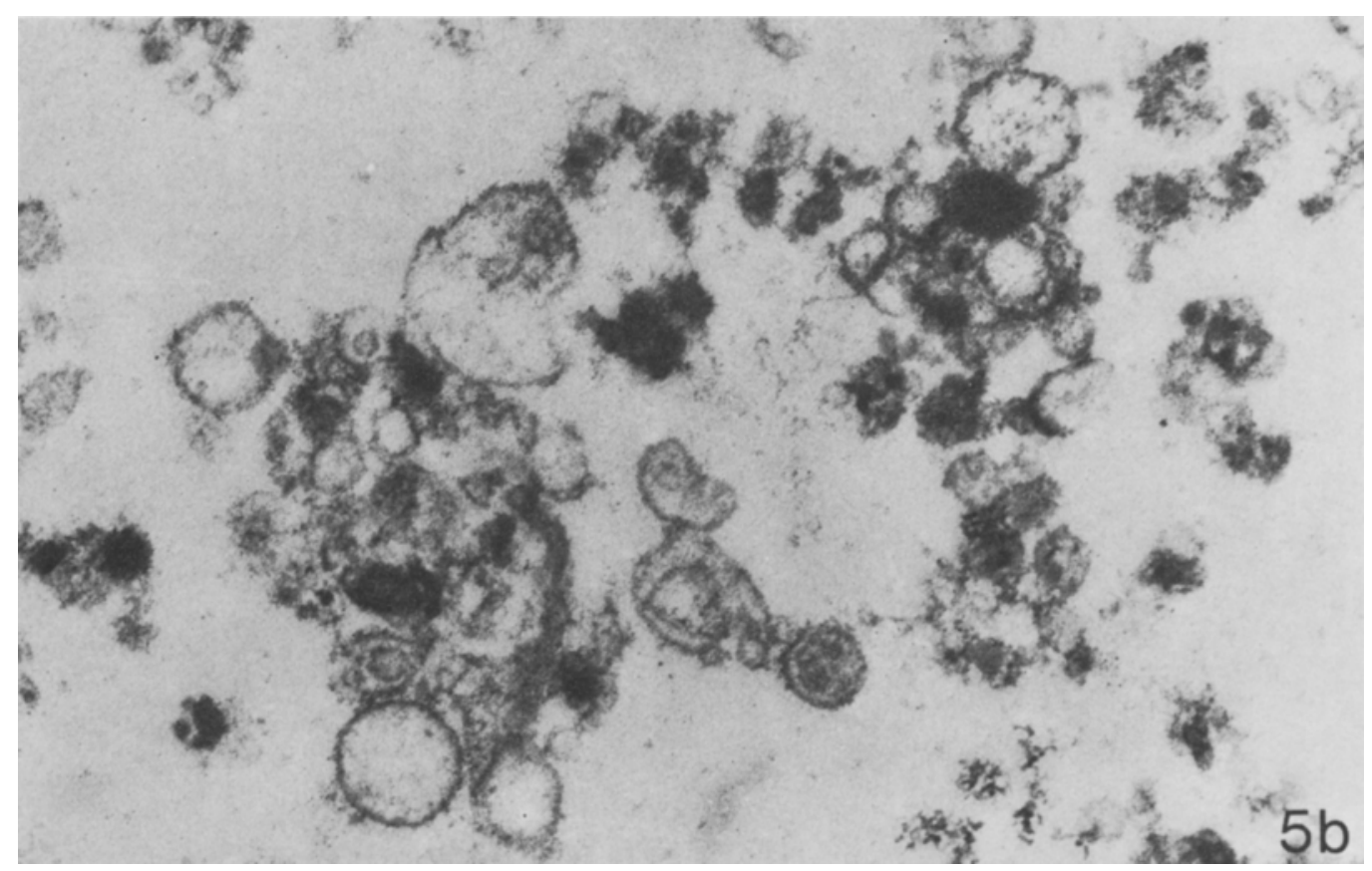

the rough microsomes from mutant endosperm were derived from band I they are somewhat larger, with a greater polysome density, than the band II microsomes prepared from Bomi endosperm.

\subsection{Microsome-directed cell-free synthesis of barley endosperm proteins}

The ability of rough and stripped microsomes and polysomes to stimulate protein synthesis in the wheat-germ cell-free protein synthesizing system was investigated (Table II). Rough microsomes from both Bomi and mutant endosperm, stimulated the incorporation of ${ }^{35} \mathrm{~S}$ methionine into hot $10 \%$ TCA-insoluble proteins five-fold. The stripped microsomes derived from Bomi and mutant endosperms were unable to direct protein synthesis, providing further evidence of the complete removal of the membrane-bound polysomes. Bomi polysomes stimulated protein synthesis 36 fold and mutant polysomes 17 fold.

The translation products of the rough micro- somes and polysomes from Bomi and mutant endosperm, with properties characteristic of the hordeins, were selectively extracted into $55 \%$ isopropanol and analysed by SDS-PAGE and fluorography (Figure 6). All the major polypeptides comprising native hordein and ranging in molecular weight from 27 to 67 kilodaltons (tracks 1 and 9) were synthesized by Bomi rough microsomes (track 2). Comparison of the peptide patterns of track 1 with track 2 reveals that the newly synthesized hordein polypeptides have a higher apparent molecular weight than the native polypeptides. Proteins soluble in 55\% isopropanol were not found among the translation products of mutant rough microsomes (track 3), in spite of the fact that they stimulated protein synthesis to the same extent as Bomi rough microsomes (Table II). The presence of polypeptides, with molecular weights lower than 27 kilodaltons among the isopropanol-soluble translation products of polysomes and rough microsomes is attributable to premature chain termination in the in vitro system. 
Table II

Cell-free protein synthesis directed by polysomes, rough and stripped microsomes from Bomi and mutant no. 1508 endosperms. Rough and stripped microsomes and initially membrane-bound polysomes were prepared from 20 day old Bomi and mutant endosperms. Cell-free protein synthesis was performed in the standard reaction mixture as described under Materials and Methods (2.8.). Results are expressed as hot $10 \%$ TCA-insoluble cpm per $A_{260}$ unit of added template or $0.6 A_{260}$ units of stripped microsomes, the equivalent of $1 A_{260}$ unit of rough microsomes.

\begin{tabular}{|c|c|c|c|}
\hline Template & $\begin{array}{l}\text { Co-translational } \\
\text { additions }\end{array}$ & $\begin{array}{l}\mathrm{cpm} \cdot \mathrm{A}_{260} \\
\text { unit template }\end{array}$ & $\begin{array}{l}\text { Stimulation } \\
\text { over wheat-germ }\end{array}$ \\
\hline \multicolumn{4}{|l|}{ A. } \\
\hline None & & 16,550 & \\
\hline \multicolumn{4}{|l|}{ Bomi: } \\
\hline rough microsomes & & 90,350 & 5.5 \\
\hline stripped microsomes & & 10,560 & 0 \\
\hline \multicolumn{4}{|l|}{ Mutant 1508: } \\
\hline rough microsomes & & 83,400 & 5.0 \\
\hline stripped microsomes & & 16,320 & 0 \\
\hline \multicolumn{4}{|l|}{ B. } \\
\hline None & & 13,870 & \\
\hline Bomi polysomes & & 498,340 & 36.0 \\
\hline Mutant polysomes & & 242,725 & 17.5 \\
\hline Bomi polysomes & $\begin{array}{r}\text { Bomi stripped } \\
\text { microsomes }\end{array}$ & 557,636 & 40.0 \\
\hline Bomi polysomes & $\begin{array}{l}\text { Mutant stripped } \\
\text { microsomes }\end{array}$ & 551,610 & 40.0 \\
\hline
\end{tabular}

\subsection{Synthesis and transport of hordeins by rough microsomes}

It has been reported previously that a portion of the hordein polypeptides synthesized in vitro by rough microsomes from Bomi endosperm, is discharged vectorially across the membrane into the lumen of the microsomes (8). By virtue of their deposition within the microsomes, these polypeptides are inaccessible to enzymic proteolysis. The co-translational transport of all the major hordein polypeptides synthesized in vitro by Bomi rough microsomes is demonstrated in the fluorogram seen in Figure 6. Track 7 reveals the hordein polypeptides inaccessible to chymotrypsin digestion, the polypeptides with a molecular weight of 35 to 38 kilodaltons being the least effectively protected. Detergent solubilization of the microsomal membranes with
Triton X-100, exposes the transported polypeptides to proteolytic attack (track 8).

There was no evidence that rough microsomes from mutant endosperm could either synthesize or transport hordein polypeptides (Figure 6, tracks 3, 4, and 5).

\subsection{Reconstitution of rough microsomes}

The hordein polypeptides, synthesized in vitro by Bomi polysomes (Figure 8, track 2), are shown to be totally susceptible to chymotrypsin digestion (track 7). When polysomes and stripped microsomes from Bomi endosperm are combined in an in vitro assay, the net stimulation of protein synthesis is unaffected (Table II), and the synthesis of hordein polypeptides as revealed by SDS-PAGE and fluorography is 
qualitatively unchanged (Figure 7, tracks 2 and 3). Bomi stripped microsomes had no detectable template activity for $55 \%$ isopropanol-soluble proteins (figure 8 , track 6 ).

In order to assess the extent of functional polysome-membrane binding, the in vitro assay mixtures of combined Bomi polysomes and stripped microsomes were post-translationally treated with chymotrypsin. A proportion of all the major hordein polypeptides synthesized by the polysomes were protected from proteolysis by the presence of stripped microsomes during

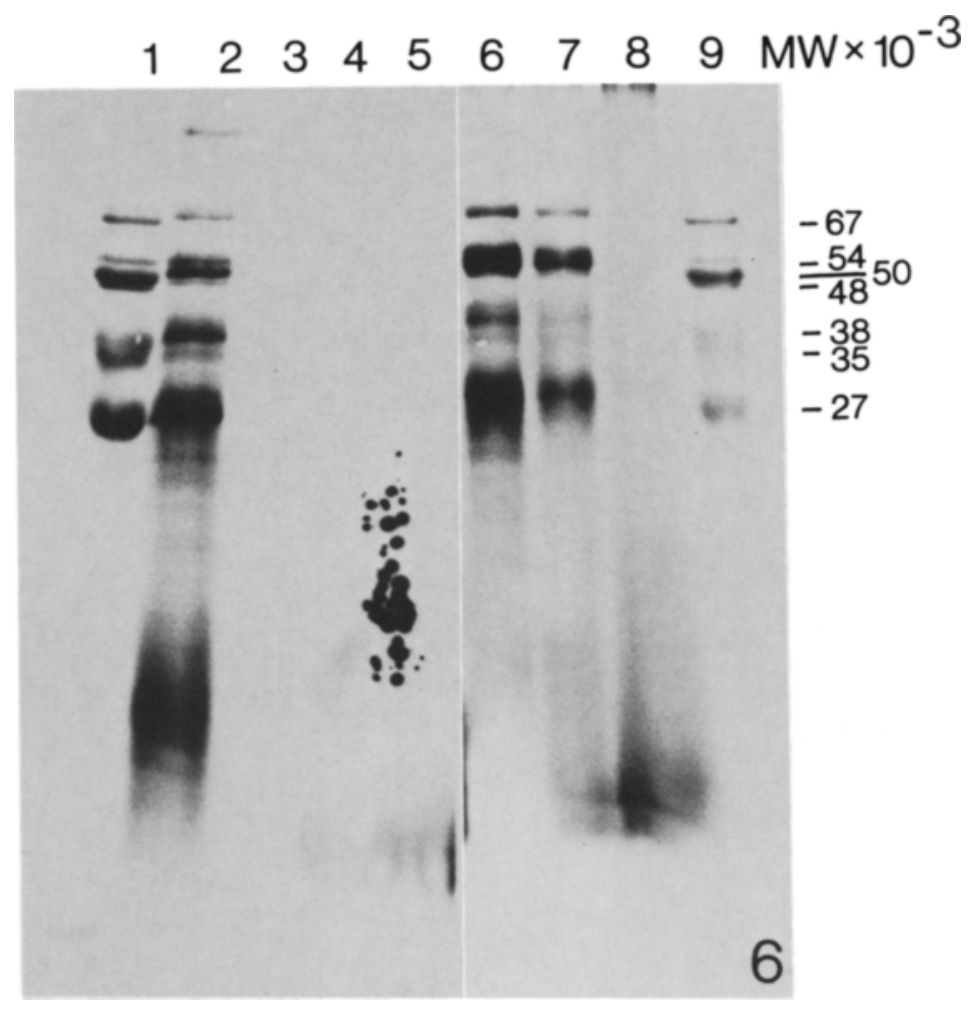

Figure 6. SDS-PAGE of 55\% isopropanol-soluble translation products of rough microsomes from Bomi and mutant no. 1508 endosperms inaccessible to enzymic proteolysis. Cell-free protein synthesis was performed with rough microsomes prepared from 20 day old Bomi and mutant endosperms. The 55\% isopropanol-soluble translation products remaining after 30 min treatment with chymotrypsin at $0^{\circ} \mathrm{C}$ were analysed by electrophoresis and fluorography as described under Materials and Methods (2.9.). The fluorogram shows translation products after the following treatments. Tracks 1 and 9 , native ${ }^{14} \mathrm{C}$-hordein marker.

Bomi rough microsomes 
in vitro translation (Figure 8, track 3 ). It may be concluded therefore that functional reconstitution of rough microsomes had been achieved. The extent of co-translational, hordein polypeptide transport on reconstituted rough microsomes (Figure 8, track 3) was qualitatively

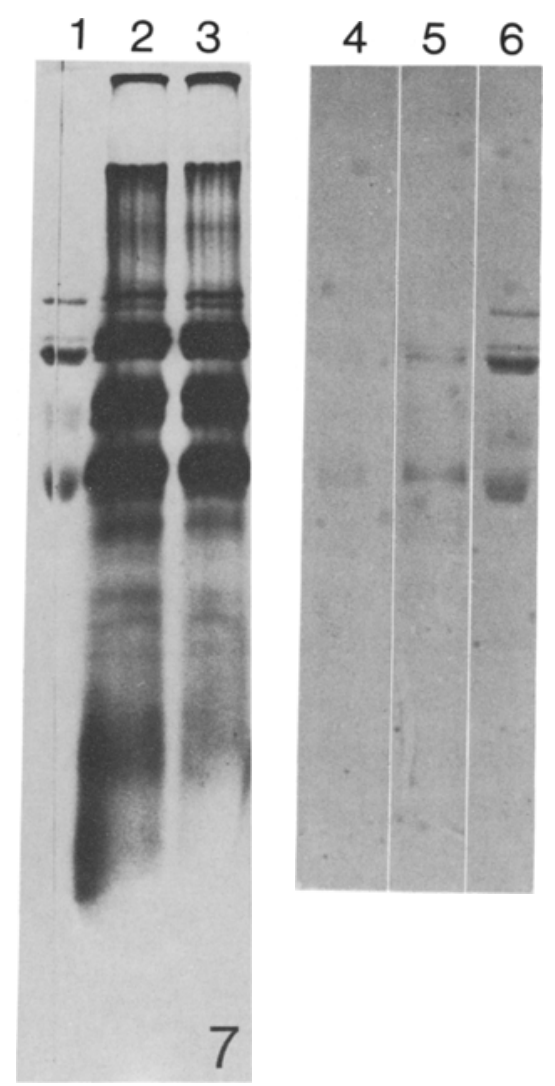

Figure 7. SDS-PAGE of $55 \%$ isopropanol-soluble translation products of Bomi polysomes synthesized in the presence of stripped microsomes from Bomi and mutant no. 1508 endosperms. Cell-free protein synthesis was performed with initially membranebound Bomi polysomes and stripped microsomes prepared from 20 day old Bomi and mutant endosperms. The 55\% isopropanol-soluble translation products were analysed by electrophoresis and fluorography as described under Materials and Methods (2.9.). The fluorogram shows native ${ }^{14} \mathrm{C}$-hordein marker, tracks 1 and 6; translation products from Bomi polysomes, tracks 2 and 5 ; translation products of Bomi polysomes combined with Bomi stripped microsomes, track 3 or mutant stripped microsomes, track 4 , The fluorogram of tracks 1,2 and 3 and the fluorogram of tracks 4,5 and 6 were exposed for 7 and 3 days, respectively. similar to that of native rough microsomes from Bomi (Figure 6, track 7). The protection of the polypeptides of 35 to 38 kilodaltons molecular weight was again found to be the least effective.

Solubilization of the vesicle membranes with Triton X-100 exposed the transported hordein polypeptides, synthesized on reconstituted rough microsomes, to chymotrypsin digestion (Figure 8, track 5). In this instance, the combination of detergent solubilized membranes with the in vitro translation products, appears to have prevented their complete proteolysis, leaving a residual of inaccessible hordein polypeptides.

The transport of completed hordein polypeptides into the lumen of the microsome was also investigated. Stripped microsomes were added to in vitro polysome assay mixtures after 30 $\min$, when in vitro protein synthesis is terminated (5), and the incubations then continued for a further $30 \mathrm{~min}$ (Figure 8, track 4). Protection from proteolysis of in vitro synthesized, completed hordein polypeptides by stripped microsomes was similar to the protection of hordein polypeptides synthesized on reconstituted rough microsomes (Figure 8 , track 3). One may conclude that Bomi microsomes confer cotranslational and post-translational protection on in vitro synthesized hordein polypeptides against proteolytic digestion.

Rough microsomes from mutant endosperm fail to synthesize detectable hordein polypeptides, making it impossible to assess their capacity to transport these proteins (Figure 6, tracks 3, 4 and 5). However, mutant polysomes can synthesize a small amount of certain hordein polypeptides (Figure 9, track 2), and their potential for reconstitution with mutant stripped microsomes could thus be investigated. The absence of hordein synthesizing activity in the mutant stripped microsomes had been confirmed by SDS-PAGE and fluorography of the in vitro translation products (Figure 8, track 11). All the hordein polypeptides synthesized in vitro on mutant polysomes in combination with stripped microsomes were accessible to proteolysis (Figure 9, tracks 2,6 and 7), indicating that reconstitution of rough microsomes and cotranslational hordein polypeptide transport had failed to occur. 


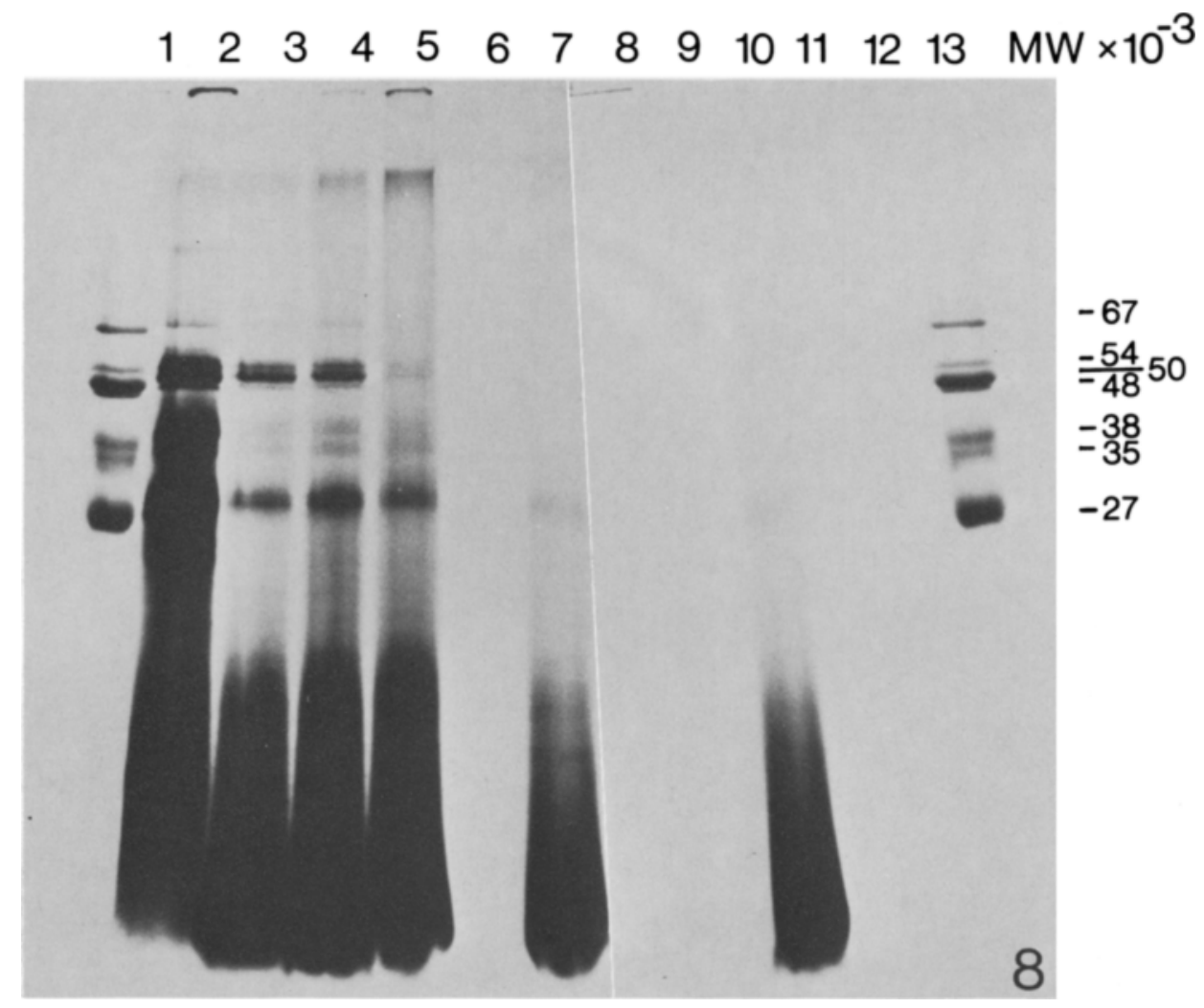

Figure 8. SDS-PAGE of 55\% isopropanol-soluble translation products of rough microsomes reconstituted from Bomi polysomes and stripped microsomes from Bomi or mutant no. 1508 endosperms. Cell-free protein synthesis was performed with initially membrane-bound Bomi polysomes and stripped microsomes prepared from Bomi and mutant endosperms. The $55 \%$ isopropanol-soluble translation products remaining after 30 min treatment with chymotrypsin at $0^{\circ} \mathrm{C}$, were analysed by electrophoresis and fluorography as described under Materials and Methods (2.9.). The fluorogram shows translation products after the following treatments. Tracks 1 and 13 , native ${ }^{14} \mathrm{C}$-hordein marker.

\begin{tabular}{|c|c|c|c|c|c|}
\hline Track & Template & $\begin{array}{c}\text { Co-translation } \\
\text { additions }\end{array}$ & $\begin{array}{l}\text { Post-translation } \\
\text { additions }\end{array}$ & $\begin{array}{c}\text { Chymotrypsin } \\
\left(0.4 \mathrm{mg} \cdot \mathrm{ml}^{-1}\right)\end{array}$ & $\begin{array}{c}\text { Triton } \\
\mathrm{X}-100(1 \%)\end{array}$ \\
\hline 2 & Bomi polysomes & 0 & 0 & 0 & 0 \\
\hline 3 & Bomi polysomes & Bomi stripped microsomes & 0 & + & 0 \\
\hline 4 & Bomi polysomes & 0 & Bomi stripped microsomes & + & 0 \\
\hline 5 & Bomi polysomes & Bomi stripped microsomes & 0 & + & + \\
\hline 6 & Bomi polysomes & Bomi stripped microsomes & 0 & 0 & 0 \\
\hline 7 & Bomi polysomes & 0 & 0 & + & 0 \\
\hline 8 & Bomi polysomes & Mutant stripped microsomes & 0 & + & 0 \\
\hline 9 & Bomi polysomes & Mutant stripped microsomes & 0 & + & + \\
\hline 10 & Bomi polysomes & 0 & $\begin{array}{l}\text { Mutant stripped } \\
\text { microsomes }\end{array}$ & + & 0 \\
\hline 11 & 0 & Mutant stripped microsomes & 0 & 0 & 0 \\
\hline 12 & $\begin{array}{l}\text { Micrococcal } \\
\text { nuclease-treated } \\
\text { wheat germ }\end{array}$ & 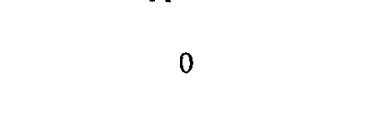 & 0 & 0 & 0 \\
\hline
\end{tabular}




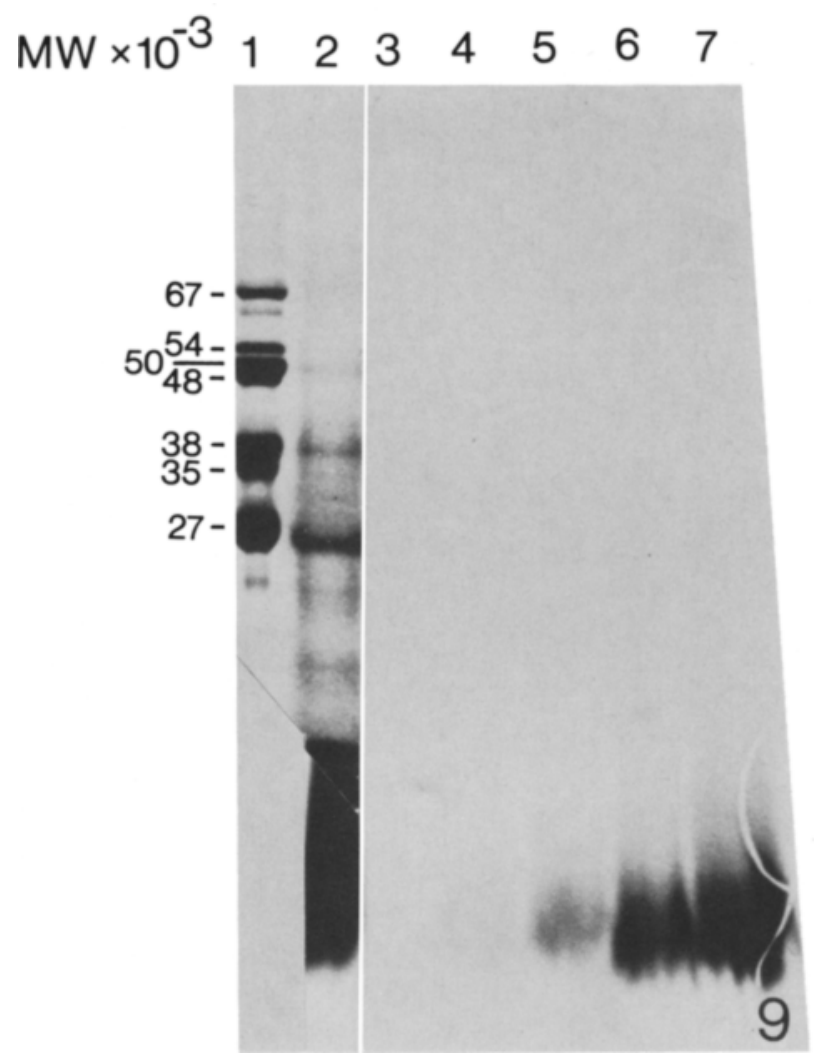

Figure 9. SDS-PAGE of 55\% isopropanol-soluble translation products of microsomes reconstituted from mutant no. 1508 polysomes and stripped microsomes from Bomi and mutant endosperms. Cell-free protein synthesis was performed with initially membrane-bound mutant polysomes and stripped microsomes prepared from 20 day old Bomi and mutant endosperms. The 55\% isopropanol-soluble translation products remaining after 30 min treatment with chymotrypsin at $0^{\circ} \mathrm{C}$, were analysed by electrophoresis and fluorography as described under Materials and Methods (2.9.). The fluorogram shows translation products after the following treatments. Track 1 , native ${ }^{14} \mathrm{C}$-hordein marker.

$\begin{array}{lcccc}\text { Track } & \text { Template } & \text { Co-translational } & \text { Chymotrypsin } & \text { Triton X-100 } \\ 2 & \text { Mutant polysomes } & \text { additions } & \left(0.4 \mathrm{mg} \cdot \mathrm{ml}^{-1}\right) & (1 \%) \\ 3 & \text { Mutant polysomes } & 0 & 0 & 0 \\ 4 & \text { Mutant polysomes } & \text { Bomi stripped microsomes } & + & 0 \\ 5 & \text { Mutant polysomes } & \text { Bomi stripped microsomes } & + & 0 \\ 6 & \text { Mutant polysomes } & \text { Mutant stripped microsomes } & + & + \\ 7 & \text { Mutant polysomes } & \text { Mutant stripped microsomes } & + & +\end{array}$

\subsection{Reconstitution of hybrid rough microsomes}

The formation of functional rough microsomes from mutant polysomes and Bomi stripped microsomes was investigated. The hordein polypeptides synthesized in vitro, in assays containing mutant polysomes and Bomi stripped microsomes, were completely digested by chymotrypsin in the presence or absence of Tri- 
ton X-100 (Figure 9, tracks 4 and 5). These results indicated that while the mutant polysomes may have become membrane-bound, their in vitro translation products were not discharged vectorially and thus functional reconstitution had failed to occur.

The characteristics of mutant rough microsome assembly were further investigated in an attempt to reconstitute functional rough microsomes from Bomi polysomes and mutant stripped microsomes. Mutant stripped microsomes slightly increased the net stimulation of protein synthesis by Bomi polysomes (Table IIB). However, in contrast to Bomi stripped microsomes, the mutant stripped microsomes inhibited the in vitro synthesis of hordein polypeptides by Bomi polysomes (Figure 7, tracks 3 and 4). Functional reconstitution was unsuccessful, since these few in vitro synthesized hordein polypeptides were not protected from proteolysis by co-translational transport into the lumen of the mutant stripped microsomes (Figure 8, tracks 8 and 9). Mutant stripped microsomes, added to assay mixtures after the cessation of protein synthesis, were also unable to protect hordein polypeptides synthesized in vitro by Bomi polysomes from proteolysis (Figure 8, track 10). The absence of both coand post-translational transport of in vitro synthesized hordeins by mutant stripped microsomes in reconstitution assays, strongly supports the hypothesis that alterations in membrane structure and function contribute to the failure of mutant rough microsomes to synthesize and transport hordein polypeptides in vitro.

\section{DISCUSSION}

Stripped microsomes were prepared from rough microsomes of Bomi and mutant no. 1508 endosperm by EDTA-treatment and dissociated membrane-bound polysomes removed subsequently by sucrose density gradient centrifugation. The purity of the stripped microsome preparation was confirmed by a variety of techniques. Advantage was taken of the low molecular weight of ribosomal proteins with respect to membrane proteins, facilitating their recognition by SDS-PAGE. Dissociation of the ribosomal and membrane proteins characteris- tic of rough microsomes by EDTA-treatment was clearly discerned. The absence of polysomes in the stripped microsome preparations viewed by electron microscopy, combined with their inability to direct protein synthesis was further evidence of their rather high purity.

Approximately $50 \%$ of all the major hordein polypeptides synthesized on rough microsomes from Bomi endosperm are released into the lumen of the microsomes, as determined by their inaccessibility to enzymic proteolysis. It was similarly demonstrated that Bomi polysomes associate with Bomi stripped microsomes and discharge a portion of the synthesized hordein polypeptides into the microsomal lumen.

The primary translation products of the hordein mRNA's are larger than the native hordeins, as previously shown (6). Figures 6 to 8 reveal that the hordein polypeptides synthesized by rough microsomes as well as polysomes are larger than those of native hordein. In a detailed comparison of hordein polypeptides synthesized by initially membrane-bound polysomes with those synthesized from purified messenger RNA and with in vivo labelled hordeins, three different mobility patterns were observable in SDS-PAGE (INGVERSEN, unpublished). The apparent molecular weights of the polysome translation products were intermediate to those of the mRNA products and the native hordein polypeptides. Further studies are required to determine if the hordein translation products from rough microsomes are identical to those made on polysomes. Several steps of processing of the primary translation products thus seem to occur in connection with the synthesis and transport of the hordein polypeptides.

Stripped microsomes permitted the posttranslational transport of hordein polypeptides synthesized on polysomes. As these polypeptides have been processed to a smaller apparent molecular weight before they had a chance to enter the microsomal membrane, this processing step does not prevent the transfer of these peptides across the membrane of the microsome.

Reconstitution of hybrid rough microsomes was used as a probe in the investigation of the 
defective synthesis of hordein in mutant no 1508. When Bomi polysomes were combined with mutant stripped microsomes, not only were the hordein translation products not transported, but the synthesis of hordeins was inhibited. Although the developing mutant endosperm is rich in rough endoplasmic reticulum (13), the membrane proteins thought to be involved in protein transfer in animal systems (21), may be defective or deficient in the mutant membranes. Differences in the composition of the high molecular weight membrane proteins found in Bomi and mutant microsomes may be relevant in this connection. Alterations in the properties of the microsome membranes were further indicated by their inability to confer post-translational protection from proteolysis on in vitro synthesized hordein polypeptides. The inhibition of polysomedirected hordein synthesis by the presence of stripped microsomes from the mutant endosperm, suggests that the endoplasmic reticulum of the latter contains components which inhibit one or more steps involved in the translation of mRNA. The successful reconstitution of functional rough microsomes, able to synthesize and transport barley endosperm storage proteins, is additional evidence to support the notion (13) that the mechanisms of protein synthesis on the endoplasmic reticulum in the plant and animal kingdoms had common features.

\section{ACKNOWLEDGEMENTS}

We would like to thank professor D. voN WETTSTEIN for valuable discussions and for helpful criticism during preparation of the manuscript. We are grateful to JEAN SAGE and A NN-SOFI STEINHOLTS for their skilful technical assistance. Verena CAMERON-Mills has been supported by a Leverhulme European Studentship, the Royal Society European Programme Fund (1977/78) and a Wellcome Travelling Research Fellowship (1978/79).

\section{REFERENCES}

1. Blobel, G. \& B. Dobberstein: Transfer of proteins across membranes. I. Presence of proteolytically processed and nonprocessed nascent im- munoglobulin light chains on membrane-bound ribosomes of murine myeloma. J. Cell Biol 67, 835-851 (1975)

2. Blobel, G. \& B. Dobberstein: Transfer of proteins across membranes. II. Reconstitution of functional rough microsomes from heterologous components. J. Cell Biol. 67, 852-862 (1975)

3. Bonner, W. M.\& R. A. LASKey: A film detection method for tritium-labelled proteins and nucleic acids in polyacrylamide gels. Eur. J. Biochem. 46, 83-88 (1974)

4. BrandT, A.: Endosperm protein formation during kernel development of wild type and a high-lysine barley mutant. Cereal Chem. 53, 890-901 (1976)

5. BrandT, A. \& J. INGVERSEN: In vitro synthesis of barley endosperm proteins of wild type and mutant templates. Carlsberg Res. Commun. 41, 312-320(1976)

6. BRANDT, A. \& J. INGVERSEN: Isolation and characterisation of hordein messenger RNA from wild type and mutant endosperms in barley. Carlsberg Res. Commun. 43, 451-469 (1978)

7. Burstein, Y. \& I. SCheChter: Amino acid sequence of the $\mathrm{NH}_{2}$-terminal extra piece segments of the precursors of mouse immunoglobulin $\lambda_{1}$ type and k-type light chains. Proc. Natl. Acad. Sci. USA 74, 716-720(1977)

8. Cameron-Mills, V., J. Ingversen \& A. Brandt: Transfer of in vitro synthesized barley endosperm proteins into the lumen of the endoplasmic reticulum. Carlsberg Res. Commun. 43, 91-102 (1978)

9. Chua, N.-H. \& P. Bennoun: Thylakoid membrane polypeptides of Chlamydomonas reinhardtii wild type and mutant strains in photosystem Il reaction center. Proc. Natl. Acad. Sci. USA 72, 2175-2179 (1975)

10. Devillers-Thiery, A., T. Kindt, G. Scheele \& G. BLOBEL: Homology in aminoterminal sequence of precursors to pancreatic secretory proteins. Proc. Natl. Acad. Sci. USA 72, 5016-5020 (1975)

11. Habener, J. F., M. Rosenblatt, B. Kemper, H. M. Kronenberg, A. Rich \& J. T. Potts JR: Preproparathyroid hormone: Amino acid sequence, chemical synthesis, and some biological studies of the precursor region. Proc. Natl. Acad. Sci. USA 75, 2616-2620(1978)

12. KRUPPA, J. \& D. D. Sabatini: Release of poly $A(+)$ messenger RNA from rat liver rough microsomes upon disassembly of bound polysomes. $\mathbf{J}$. Cell Biol. 74, 414-427 (1977)

13. Munck, L. \& D. von WetTstein: Effects of genes that change the amino acid composition of barley 
endosperm. In: Genetic improvement of seed protein. Proc. of a workshop 18-20 March 1974. National Academy of Sciences, Washington D. C. pp. 71-82 (1976)

14. PAL.ADE, G: Intracellular aspects of the process of protein synthesis. Science 189, 347-358 (1975)

15. RANDALL, L. L., S. J. S. HARDY \& L.-G. JosefsSON: Precursors of three exported proteins in Escherichia coli. Proc. Natl. Acad. Sci. USA 75, 1209-1212 (1978)

16. Randall, L. L. \& S. J. S. HaRdy: Synthesis of exported proteins by membrane-bound polysomes from Escherichia coli. Eur. J. Biochem. 75, 43-53 (1977)

17. Sabatini, D. D., Y. Tashiro \& G. E. Palade: On the attachment of ribosomes to microsomal membranes. J. Mol. Biol. 19, 503-524 (1966)

18. Shields, D. \& G. Blobel: Cell-free synthesis of fish preproinsulin, and processing by heterologous mammalian microsomal membranes. Proc. Natl. Acad. Sci. USA 74, 2059-2063 (1977)

19. Scheele, G., B. Dobberstein \& G. Blobel: Transfer of proteins across membranes. Biosynthesis in vitro of pretrypsinogen and trypsinogen by cell fractions of canine pancreas. Eur. J. Biochem. 82, 593-599 (1978)

20. Strauss, A. W., C. D. Bennett, A. M. Donohue, J. A. RoDkey \& A. W. Alberts: Rat liver preproalbumin: Complete amino acid sequence of the pre-piece. Analysis of the direct translation product of albumin messenger RNA. J. Biol. Chem. 252, 6846-6855 (1977)

21. Warren, G. \& B. Dobberstein: Protein transfer across microsomal membranes reassembled from separate membrane components. Nature 273, 569-571 (1978) 